\title{
PEMBANGUNAN \\ PELAPORAN DATA PERSEDIAAN \\ BARANG TERINTEGRASI
}

Indah Putriani Fajar Sidik, Wina Witanti, Asep Id Hadiana

Universitas Jenderal Achmad Yani (UNJANI) Jawa Barat, Indonesia

Email: moelapujar39@gmail.com,witanti@gmail.com, aih@if.unjani.ac.id

\begin{tabular}{|c|c|}
\hline INFO ARTIKEL & ABSTRAK \\
\hline $\begin{array}{l}\text { Diterima } \\
25 \text { Juli } 2021 \\
\text { Direvisi } \\
\text { 05 Agustus } 2021 \\
\text { Disetujui } \\
15 \text { Agustus 2021 }\end{array}$ & \multirow[b]{2}{*}{$\begin{array}{l}\text { Pengintegrasian sistem merupakan salah satu konsep kunci dari } \\
\text { sistem informasi yang dapat saling berhubungan satu dengan } \\
\text { yang lainnya. Integrasi secara sistem bisa terjadi dengan syarat } \\
\text { bahwa seluruh perusahaan harus menggunakan satu sumber } \\
\text { yang sama sehingga mengahsilkan sebuah sistem yang sesuai } \\
\text { dengan kebutuhan perusahaan. Salah satunya pada bagian } \\
\text { inventori pada sebuah perusahaan yang sangat berhubungan } \\
\text { erat dengan pendataan persediaan barang. Pada perusahaan } \\
\text { PDAM Tirtawening Bandung, saat ini memiliki } 3 \text { gudang yang } \\
\text { aktivitas sistem saat ini pada bagian pergudangan meliputi } \\
\text { pencatatan barang masuk, pencatatan barang keluar, } \\
\text { pengelolaan barang, surat keluar, permintaan barang, } \\
\text { pengecekan barang, dan pelaporan persediaan barang setiap } \\
\text { bulan. Sistem yang ada masih offline atau berdiri sendiri serta } \\
\text { belum terhubung dengan gudang lainnya, sehingga mengalami } \\
\text { kesulitan dalam mendapatkan informasi persediaan barang dari } \\
\text { gudang. Dengan menambahkan fitur monitoring yang akan } \\
\text { diintegrasikan kepada setiap gudang yang dapat mengontol } \\
\text { prosesn pengelolaan persediaan barang. Dengan ini } \\
\text { membutuhkan sebuah teknologi yang dapat mengintegrasikan } \\
\text { persediaan barang dari setiap gudang, mengontrol persediaan } \\
\text { barang, dapat diakses dari mana saja dan kapan saja serta cepat } \\
\text { dalam pengambilan keputusan. Tujuan dari penelitian ini } \\
\text { adalah Menghubungkan gudang pusat dengan gudang cabang. } \\
\text { Memberikan informasi yang diperbaharui secara realtime. } \\
\text { Melakukan pelaporan persediaan barang secara keseluruhan. } \\
\text { Dengan menerapkan sistem terintegrasi dapat mengetahui } \\
\text { perkembangan serta memonitoring persediaan barang dengan } \\
\text { mengetahui kondisi barang mengalami kerusakan atau tidak. } \\
\text { Pengintegrasian dilakukan pada sistem yang sudah ada dengan } \\
\text { sistem yang akan dibangun terhadap gudang lainnya sehingga } \\
\text { dalam proses pengelolaan persediaan barang dapat dilakukan } \\
\text { dengan baik, gudang pusat juga dapat melihat data barang dari } \\
\text { gudang yang lain untuk melakukan pengecekan barang yang } \\
\text { apabila membutuhkan barang serta pelaporan persediaan }\end{array}$} \\
\hline $\begin{array}{l}\text { Kata Kunci: } \\
\text { terintegrasi; } \\
\text { persediaan barang; } \\
\text { monitoring }\end{array}$ & \\
\hline v to cite: & \\
\hline & \\
\hline
\end{tabular}


barang secara keseluruhan.

\begin{abstract}
System integration is one of the key concepts of information systems that can be interconnected with one another. System integration can occur on the condition that all companies must use the same source so as to produce a system that suits the needs of the company. One of them is in the inventory section of a company that is very closely related to inventory data collection. At the PDAM Tirtawening Bandung company, currently has 3 warehouses whose current system activities in the warehousing section include recording incoming goods, recording outgoing goods, managing goods, outgoing letters, requests for goods, checking goods, and reporting inventory every month. The existing system is still offline or independent and has not been connected to other warehouses, so it is difficult to get information on inventory from the warehouse. By adding a monitoring feature that will be integrated into each warehouse that can control the inventory management process. This requires a technology that can integrate inventory from each warehouse, control inventory, can be accessed from anywhere and anytime and quickly in decision making. The purpose of this research is to connect the central warehouse with branch warehouses. Provide real-time updated information. Carry out overall inventory reporting. By implementing an integrated system, you can know the progress and monitor inventory by knowing whether the condition of the goods is damaged or not. Integration is carried out on existing systems with systems that will be built on other warehouses so goods and report inventory on a regular basis. whole.
\end{abstract} Keywords: $\quad$ that in the process of managing inventory items can be carried integrated; out properly, the central warehouse can also view data on inventory; goods from other warehouses to check goods if they need monitoring

\title{
Pendahuluan
}

Menurut (S. Pratama, 2017) Pada era globalisasi seperti sekarang ini, ilmu pengetahuan dan teknologi informasi berkembang dengan pesat sehingga diharapkan dalam memperoleh sebuah informasi bisa didapat dengan cepat dan akurat. Dengan Pengintegrasian sistem merupakan salah satu konsep kunci dari sistem informasi yang dapat saling berhubungan satu dengan yang lainnya (Agusvianto, 2017). Integrasi secara sistem bisa terjadi dengan syarat bahwa seluruh perusahaan harus menggunakan satu sumber yang sama sehingga mengahsilkan sebuah sistem yang sesuai dengan kebutuhan perusahaan (Dwi Yulianto Andie Arvian Rachmadi, 2017). Salah satunya pada bagian inventori pada sebuah perusahaan yang sangat berhubungan erat dengan pendataan persediaan barang (Hendini, 2016). Setiap pergudangan memiliki tugas untuk menyimpan, mengelola barang yang akan disimpan serta menjaga persediaan barang 
dengan baik (Kurniawan et al., 2018). Persediaan barang berfungsi untuk mengelola seluruh kegiatan persediaan barang yang dilakukan secara berulang-ulang (Muslihudin, 2016). Pada perusahaan PDAM Tirtawening Bandung, saat ini memiliki 3 gudang yang aktivitas sistem saat ini pada bagian pergudangan meliputi pencatatan barang masuk, pencatatan barang keluar, pengelolaan barang, surat keluar, permintaan barang, pengecekan barang, dan pelaporan persediaan barang setiap bulan. Sistem yang ada masih offline atau berdiri sendiri serta belum terhubung dengan gudang lainnya, sehingga mengalami kesulitan dalam mendapatkan informasi persediaan barang dari gudang (Sari \& Nuari, 2017). Dengan menambahkan fitur monitoring yang akan diintegrasikan kepada setiap gudang yang dapat mengontol prosesn pengelolaan persediaan barang (Pahlevi et al., 2021). Dengan ini membutuhkan sebuah teknologi yang dapat mengintegrasikan persediaan barang dari setiap gudang, mengontrol persediaan barang, dapat diakses dari mana saja dan kapan saja serta cepat dalam pengambilan keputusan (A. Pratama, 2018). Dengan menerapkan sistem terintegrasi dapat mengetahui perkembangan serta memonitoring persediaan barang dengan mengetahui kondisi barang mengalami kerusakan atau tidak. Pengintegrasian dilakukan pada sistem yang sudah ada dengan sistem yang akan dibangun terhadap gudang lainnya sehingga dalam proses pengelolaan persediaan barang dapat dilakukan dengan baik, gudang pusat juga dapat melihat data barang dari gudang yang lain untuk melakukan pengecekan barang yang apabila membutuhkan barang serta pelaporan persediaan barang secara keseluruhan (Sari \& Nuari, 2017).

Manfaat sebuah sistem informasi pada kegiatan pengelolaan persediaan barang yang dimiliki oleh organisasi yang dapat membantu dalam mendapatkan informasi yang diperbaharui secara realtime dan menghindari kesalahan yang akan terjadi untuk mencapai pengelolaan persediaan barang yang lebih baik (Tamodia, 2013). PDAM Tirtawening Bandung merupakan sebuah unit usaha milik daerah yang bergerak dalam distribusi air bersih bagi masyarakat. Seiring berkembangnya teknologi PDAM Tirtawening membutuhkan suatu sistem yang diperuntukkan untuk mengintegrasikan dan mengotomasikan proses bisnis terutama pada bagian pergudangan. PDAM Tirtawening Bandung saat ini memiliki 3 gudang diantaranya gudang pusat berada di PDAM Tirtawening Bandung dan gudang wilayah (daerah Cipamekolan dan daerah Cimindi). Proses aktivitas dalam pergudangan sudah terkomputerisasi, namun untuk antar gudang belum saling terhubung satu sama lain sehingga mengalami kesulitan dalam mengelola persediaan barang, informasi yang didapatkan mengenai persediaan barang kurang detail yang dapat mempengaruhi pelaporan persediaan barang. Dengan penyatuan sistem yang ada dengan teknologi untuk membentuk sistem yang lebih mampu untuk mengambil sebuah keputusan dengan meningkatkan sistem yang ada. Sehingga dapat menentukan persediaan barang dengan pengelolaan yang lebih tepat.

Menurut (Taloko et al., 2020) Berdasarkan pada uraian yang telah dirangkas diatas maka untuk membantu mengatasi permasalahan yang terjadi pada, maka pada penelitian ini akan membuat "Pembangunan Pelaporan Persediaan Barang Terintegrasi Pada PDAM Tirtawening Bandung”. Dengan ini diharapkan dapat memaksimalkan 
kinerja terintegrasi sistem yang ada dapat mengelola data persediaan barang secara realtime yang dapat membantu petugas pergudangan dalam melakukan pelaporan persediaan barang.

\section{Metode Penelitian}

\section{Pengumpulan Data}

Pengumpulan data dilakukan untuk mendapatkan data pada organisasi yang bersangkutan. Kegiatan ini dilakukan dengan cara wawancara, dan observasi serta mempelajari dokumen dari sistem yang sedang berjalan. Data ini akan digunakan untuk bahan dasar untuk melakukan analisis masalah untuk mendapatkan solusi yang terbaik.

Wawancara merupakan metode pengumpulan data yang dilakukan dengan mengajukan sebuah pertanyaan langsung kepada narasumber yang berjumlah 3 orang terkait dengan proses bisnis pada Perusahaan.

Observasi merupakan metode pengumpulan data melalui pengamatan langsung atau peninjauan secara cermat di lapangan atau lokasi penelitian. Observasi pada perusahaan PDAM Tirtawening Bandung dilakukan dengan tujuan memperoleh gambaran yang jelas mengenai masalah yang terjadi, sehingga dapat menemukan solusi untuk memecahkan suatu permasalahan tersebut.

\section{Metode Pengembangan Perangkat Lunak}

Metode pengembangan perangkat lunak adalah object oriented programming dengan menggunakan metode waterfall. Perancangan perangkat lunak yang digunakan adalah Unified Modeling Languange (UML) (Warkim \& Sensuse, 2017). Metode waterfall memiliki langkah-langkah berikut:

1. Requirement Analisis

Tahap ini pengembangan sistem diperlukan sebuah komunikasi yang bertujuan untuk memahami perangkat lunak yang diharapkan oleh pengguna dan batasan perangkat lunak tersebut. Informasi ini biasanya dapat diperoleh melalui wawancara, diskusi survey langsung yang dianalisis untuk mendapatkan data yang dibutuhkan oleh pengguna.

2. System Design

Spesifikasi kebutuhan dari tahapan sebelumnya akan dipelajari dalam fase ini dan desain sistem yang disiapkan. Desain sistem membantu dalam menentukan perangkat lunak (hardware) dan sistem persyaratan dan juga membantu dalam mendefinisikan arsitektur sistem secara keseluruhan. Tahap ini dilakukan membuat perancangan sistem terhadap solusi dari permasalahan yang ada dengan menggunakan metode UML (Unified Modelling Language) yaitu Use Case Diagram, Aktivity Diagram, Scenario Diagram, Sequence Diagram, Class Diagram, Dan Deployment Diagram dengan menggunakan tools Astah yang berhubungan dengan entitas, flowmap dimana akan merancang proses aliran data yang akan dibuat. Perancangan database menggunakan Mysql, dan 
perancangan antar muka menggunakan tools Balsamiq Mockup. Tahapan ini menghasilkan dokumen yang berisi pemodelan perancangan perangkat lunak.

3. Implementasi

Pada tahap ini, sistem pertama kali dikembangkan pada program kecil yang disebut unit, yang akan terintegrasi dalam tahap selanjutnya. Setiap unit yang akan dikembangkan akan diuji untuk fungsionalitas yang disebut unit testing yang akan menggunakan bahasa pemrograman PHP dan Mysql.

4. Integration dan Testing

Pada tahap ini seluruh unti yang akan dikembangkan dalam tahap implementasi yang diintegrasikan ke dalam sistem setelah terintegrasi oleh seluruh sistem yang diuji untuk mengecek setiap kegagalan maupun kesalahan. Pengujian akan dilakukan dengan menggunakkan Blackbox Testing dimana akan menguji seluruh fungsi yang akan diuji dengan satu persatu agar mengetahui terdapat kesalahan atau tidak. Pada tahap ini menggunakan visual studio code sebagai tool texteditor untuk mengcode program yang akan dibangun dengan menggunakan CI (CodeIgneter) sebagai framework database menggunakan Mysql dan XAMPP sebagai penggunaan server.

\section{Hasil dan Pembahasan}

Perancangan sistem yang dilakukan setelah melakukan proses analisis data. Berdasarkan data yang telah dilakukan sebelumnya, maka perancangan untuk sistem yang diusulkan menggunakan $U M L$ sebagai alat untuk mengidentifikasi kebutuhan pada sistem.

\section{A. Usecase Diagram}

Use case diagram menggambarkan fungsionalitas dari sebuah sistem. Sebuah use case merepresentasikan sebuah interaksi antara actor dengan sistem, actor yang dapat berupa orang, peralatan atau sistem lain yang berinteraksi dengan sistem yang akan dibandung dan juga menggambarkan fungsionalitas sistem atau persyaratanpersyaratan yang harus dipenuhi sistem dari pengguna (Wijaya et al., 2013). 


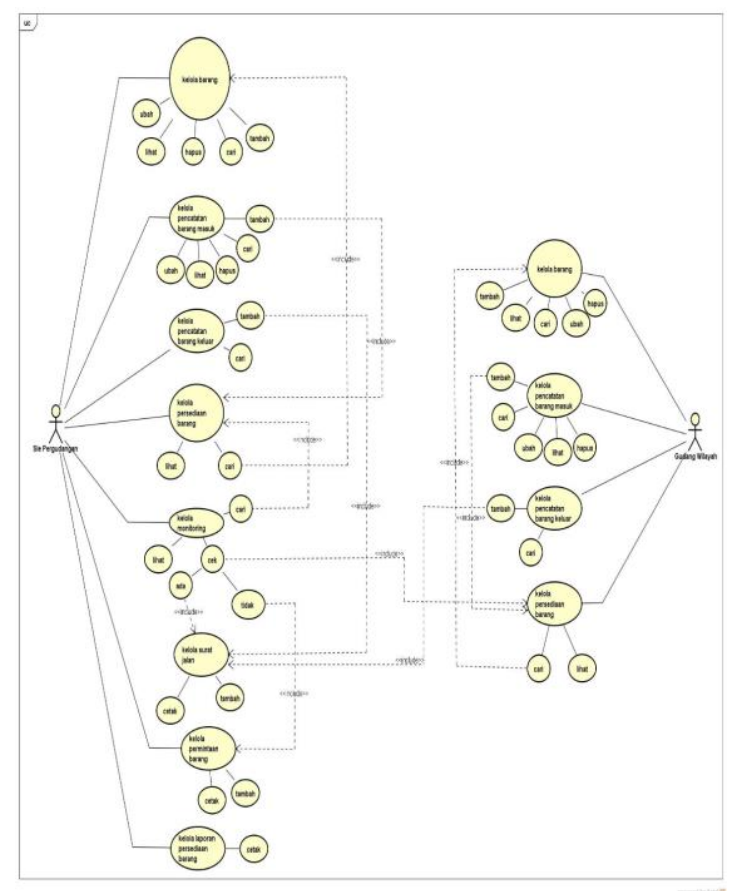

\section{Gambar 1 \\ Use case Diagram}

Pada gambar 1 Use case Diagram ini terdiri dari 2 aktor yang terlibat dalam penggunaan sistem pembangunan pelaporan data persediaan barang terintegrasi yang terdiri dari :

\section{a. Pergudangan}

Pada penggunaan pembangunan pelaporan data persediaan barang terintegrasi pergudangan dapat mengelola beberapa modul yang dibutuhkan seperti pencatatan barang masuk, pencatatan barang keluar, data barang, persediaan barang, monitoring persediaan barang, surat permintaan barang, surat jalan dan pelaporan persediaan barang.

b. Gudang wilayah

Pada gudang wilayah merupakan gudang cabang yang berperan membantu gudang pusat, hanya mengatur barang yang akan disimpan pada gudang cabang sesuai wilayah atau lokasi gudang tersebut. Gudang wilayah dapat mengelola beberapa modul seperti kelola barang, pencatatan barang masuk, pencatatan barang keluar, dan persediaan barang.

Pada gambar use case diagram diatas menjelaskan bahwa bagian pergudangan melakukan aktivitas pergudangan secara umum seperti menginput data data, mencatat barang masuk, mencatat barang keluar, mengecek dan mengontrol persediaan barang. Pada sistem ini persediaan barang terintegrasi dengan gudang wilayah, sehingga sie pergudangan dapat mengontrol persediaan barang yang ada pada gudang wilayah sehingga dapat mengambil keputusan terhadap persediaan barang pada setiap gudang. Pengecekan barang dilakukan apabila dari pihak lain membutuhkan barang, maka bagian pergudangan akan mengecek seluruh data 
persediaan barang yang ada pada setiap gudang. Jika barang yang dibutuhkan tersedia, maka sie pergudangan langsung membuat surat jalan dan mencatat barang keluar. Apabila barang yang dibutuhkan tidak tersedia, maka sie pergudangan akan membuat surat permintaan barang yang akan ditujukan kepada Ka. Bagian Perbekalan dan Perawataan untuk mengadakan barang yang dibutuhkan. Setelah di proses kegiatan tersebut, maka dapat dibuat pelaporan persediaan secara keseluruhan.

\section{B. Activity Diagram}

Activity diagram menggambarkan aktivitas yang dilakukan pada sistem. Dimulai dari proses awal sampai akhir yang memodelkan alur kerja.

\section{Activity Diagram Pencatatan Barang Masuk}

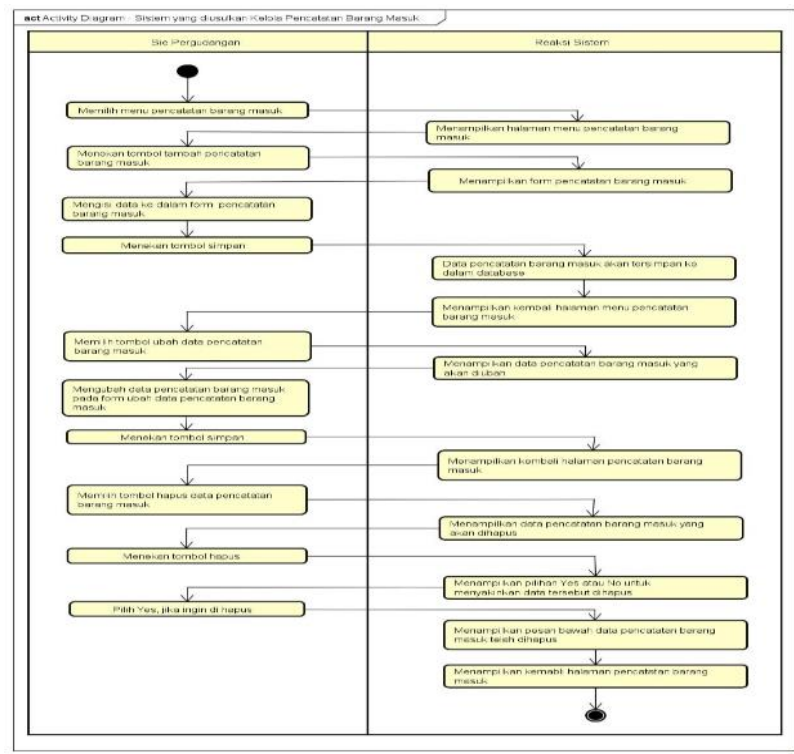

Gambar 2

Activity Diagram Pencatatan Barang Masuk

\section{Activity Diagram Pencatatan Barang Keluar}

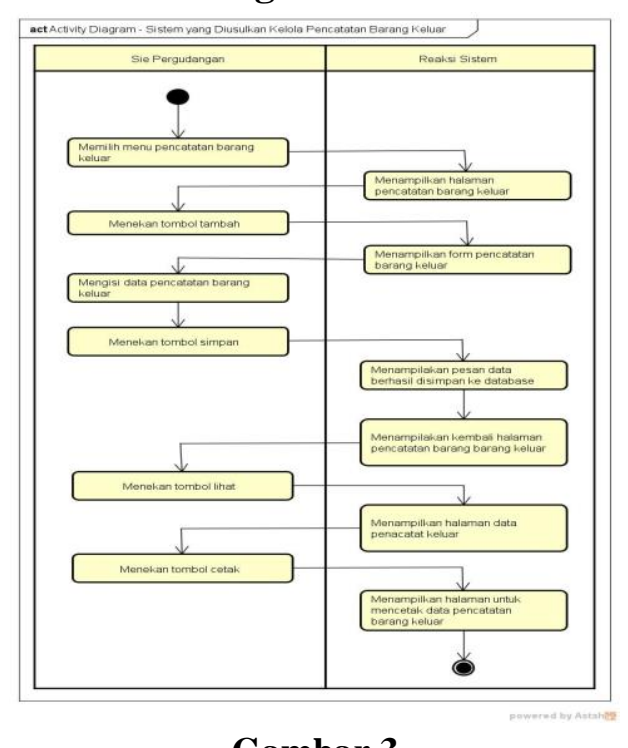

Gambar 3

Activity Diagram Pencatatan Barang Keluar 


\section{Activity Diagram Surat Permintaan Barang}

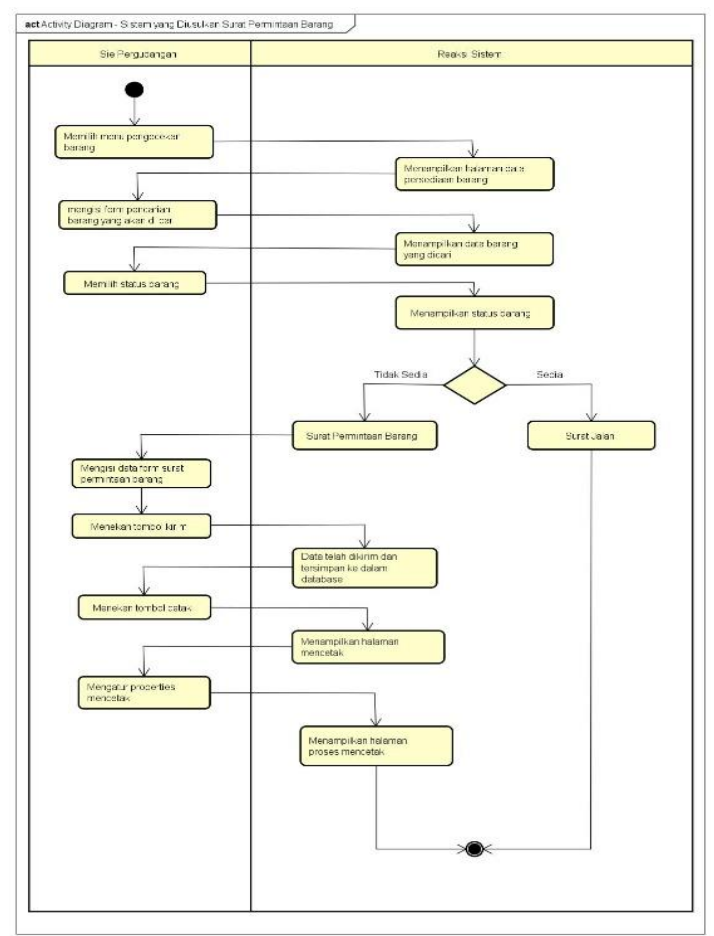

Gambar 4.

Activity Diagram Surat Permintaan Barang

\section{Activity Diagram Surat Jalan}

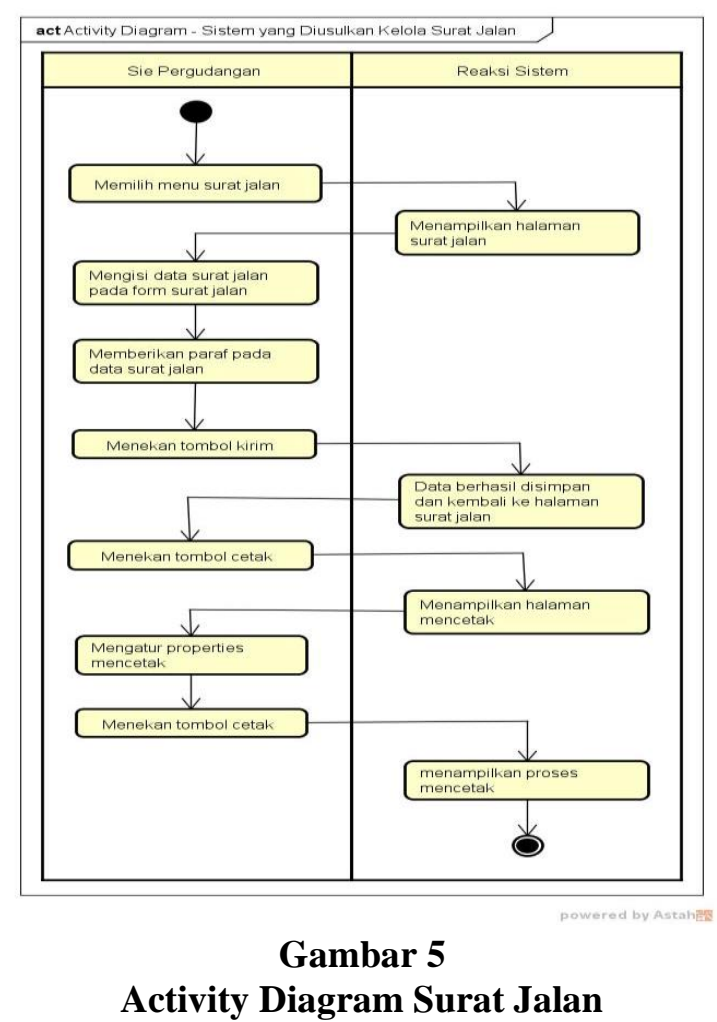


Indah Putriani Fajar Sidik, Wina Witanti, Asep Id Hadiana

\section{Activity Diagram Monitoring Persediaan Barang}

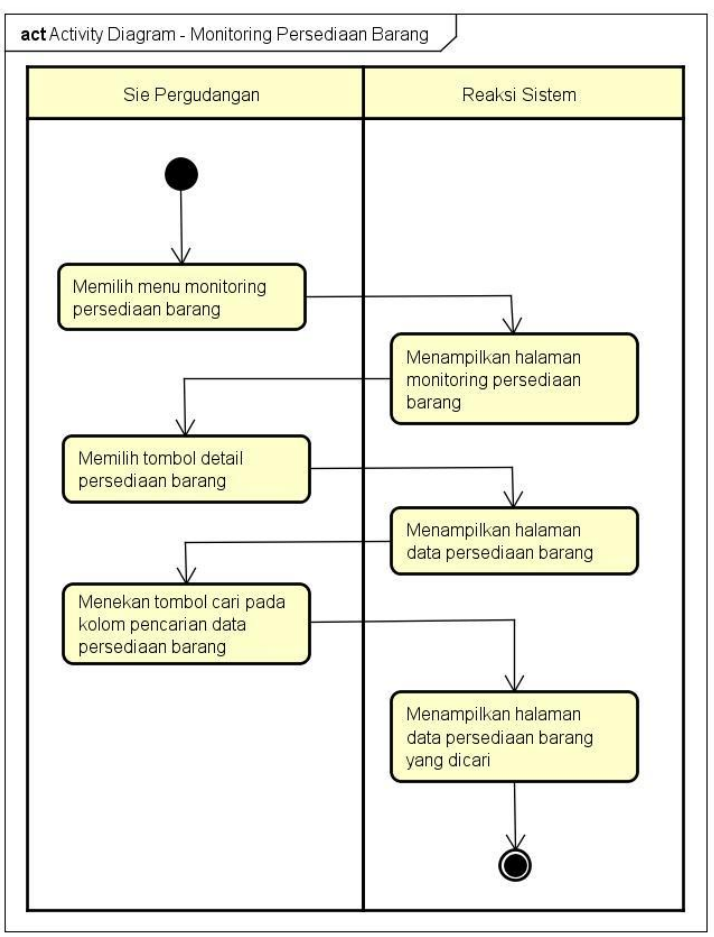

Gambar 6

Activity Diagram Monitoring Persediaan Barang

6. Activity Digram Laporan Persediaan Barang

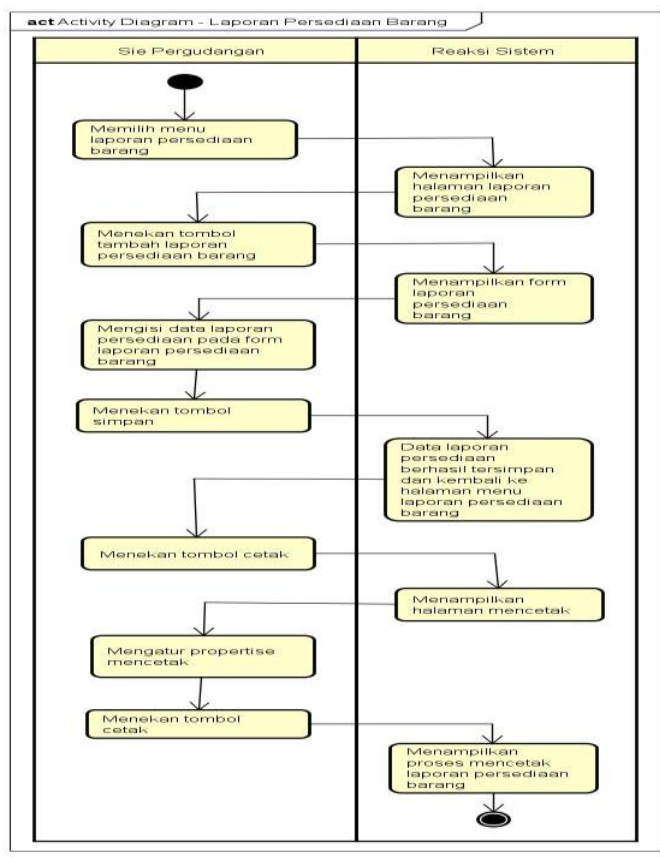

Gambar 7

Activity Diagram Laporan Persediaan Barang 


\section{Sequence Diagram}

Sequence diagram menjelaskan sebuah interaksi objek yang disusun dalam suatu urutan tertentu yang memperlihatkan tahap demi tahap yang seharusnya terjadi untuk menghasilkan sesuatu didalam usecase yang telah digambarkan (Yuhendra, 2014).

1. Sequence Diagram Tambah Pencatatan Barang Keluar

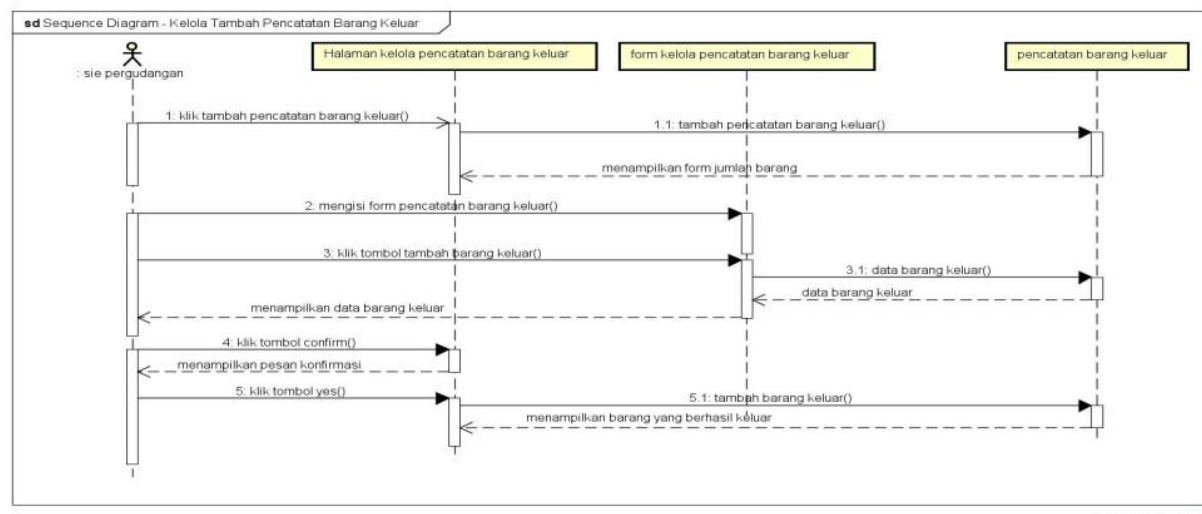

Gambar 8

Sequence Diagram Pencatatan Barang Keluar

2. Sequence Diagram Tambah Pencatatan Barang Masuk

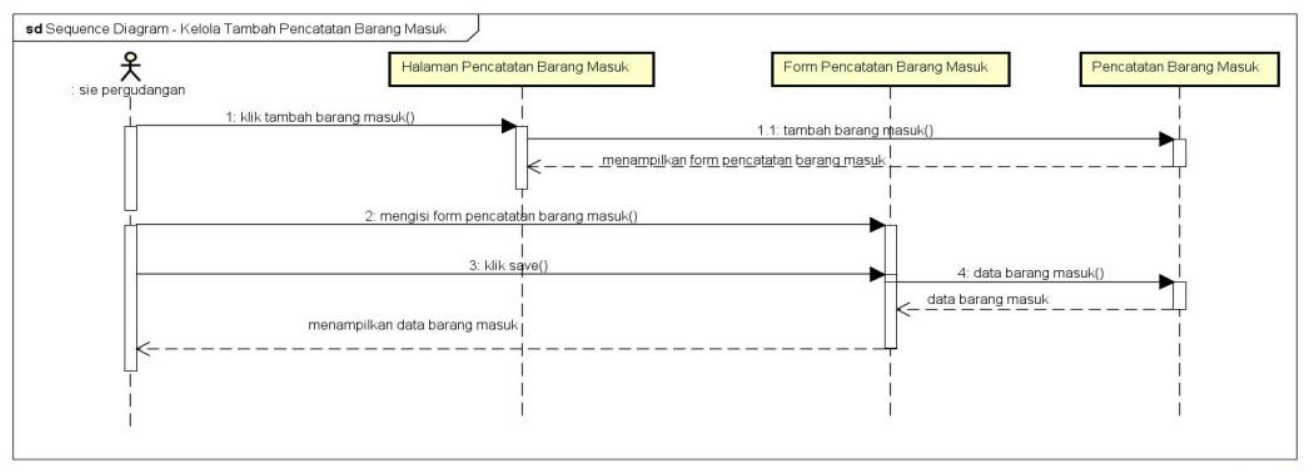

Gambar 9

Sequence Diagram Tambah Pencatatan Barang Masuk

\section{Sequence Diagram Lihat Monitoring Persediaan Barang}

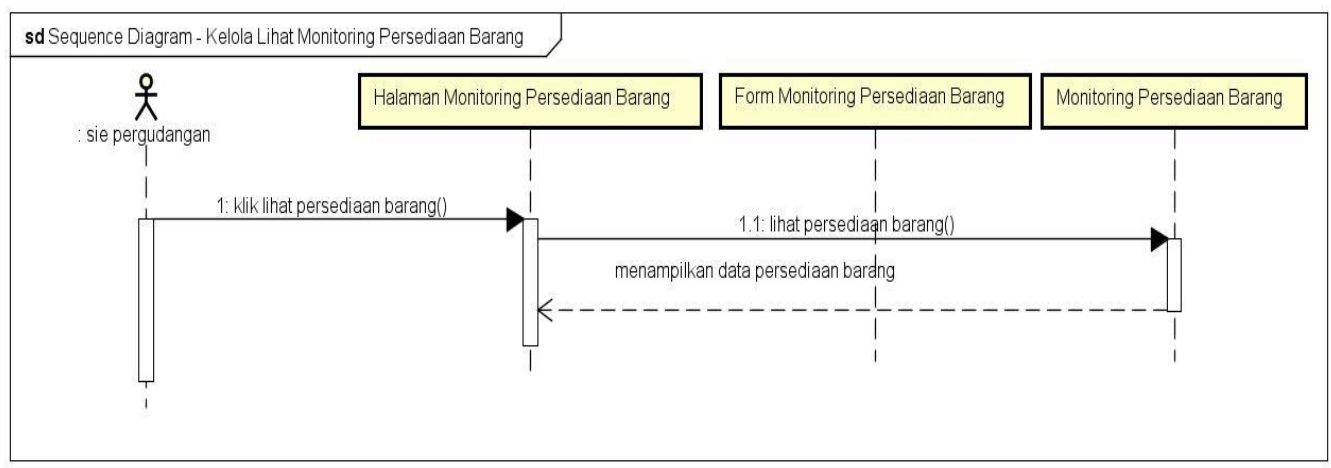

Gambar 10

Sequence Diagram Lihat Monitoring Persediaan Barang 


\section{Sequence Diagram Cetak Surat Jalan}

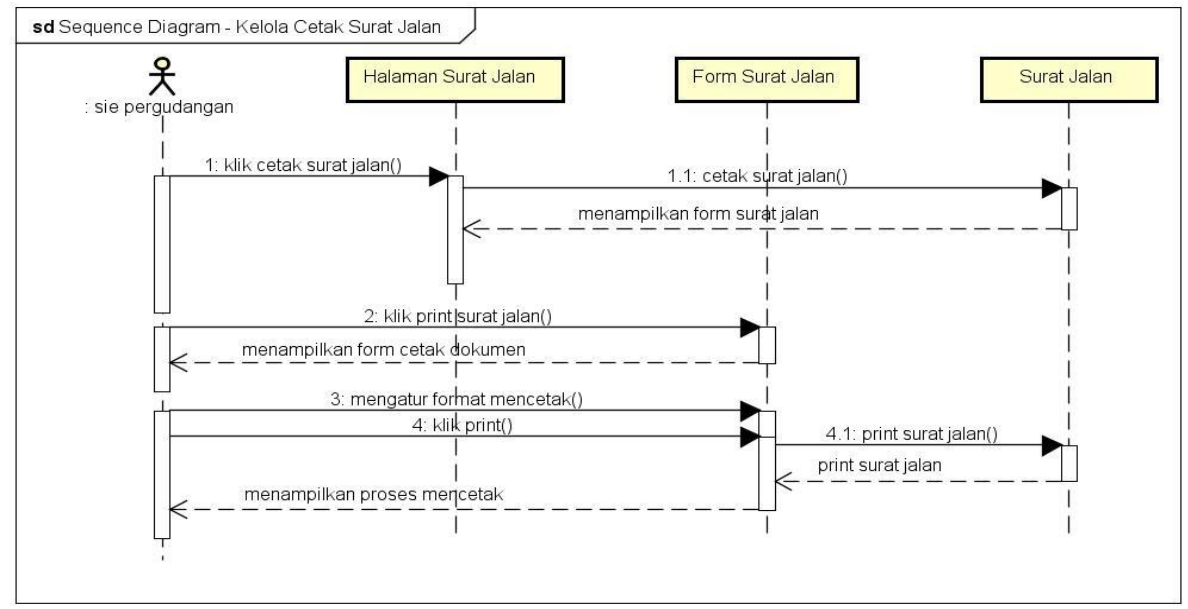

Gambar 11

Seuqence Diagram Cetak Surat Jalan

\section{Sequence Diagram Cetak Laporan Persediaan Barang}

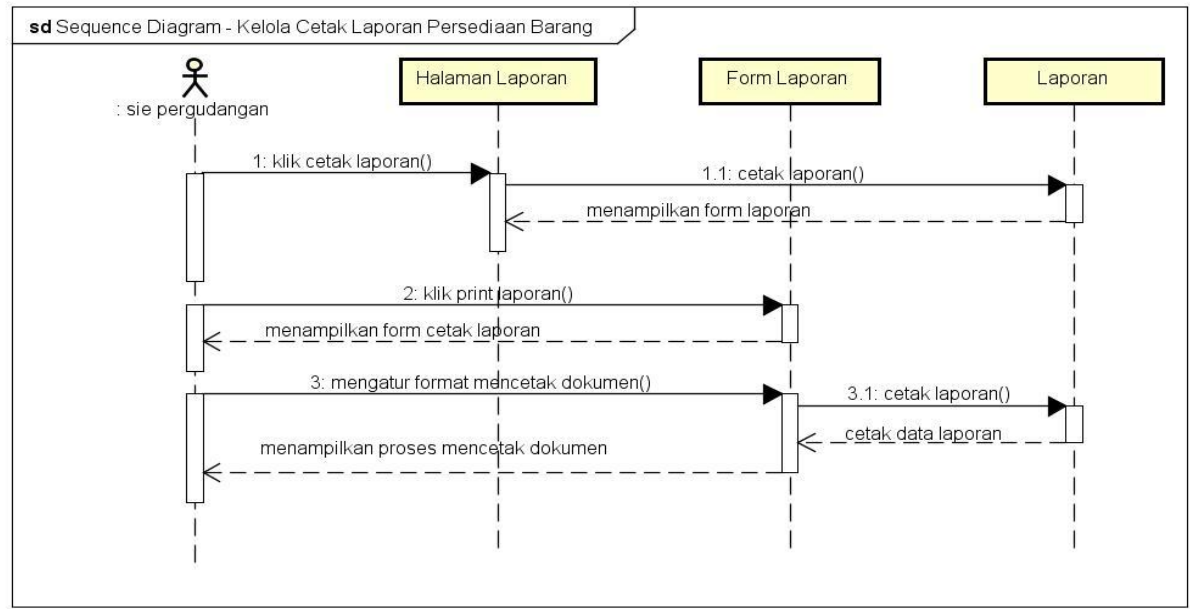

Gambar 12

Sequence Diagram Laporan Persediaan Barang

\section{Class Diagram}

Class diagram menjelaskan sebuah diagram yang menunjukan class yang ada pada sistem dan hubungannya secara logic dan spesifikasi jika diintansikan akan menghasilkan sebuah objek dan merupakan inti dari pengembangan dan desain berorientasi objek. Class juga menggambarkan keadaan (atribut atau property) pada system (Zaidir, 2017). 


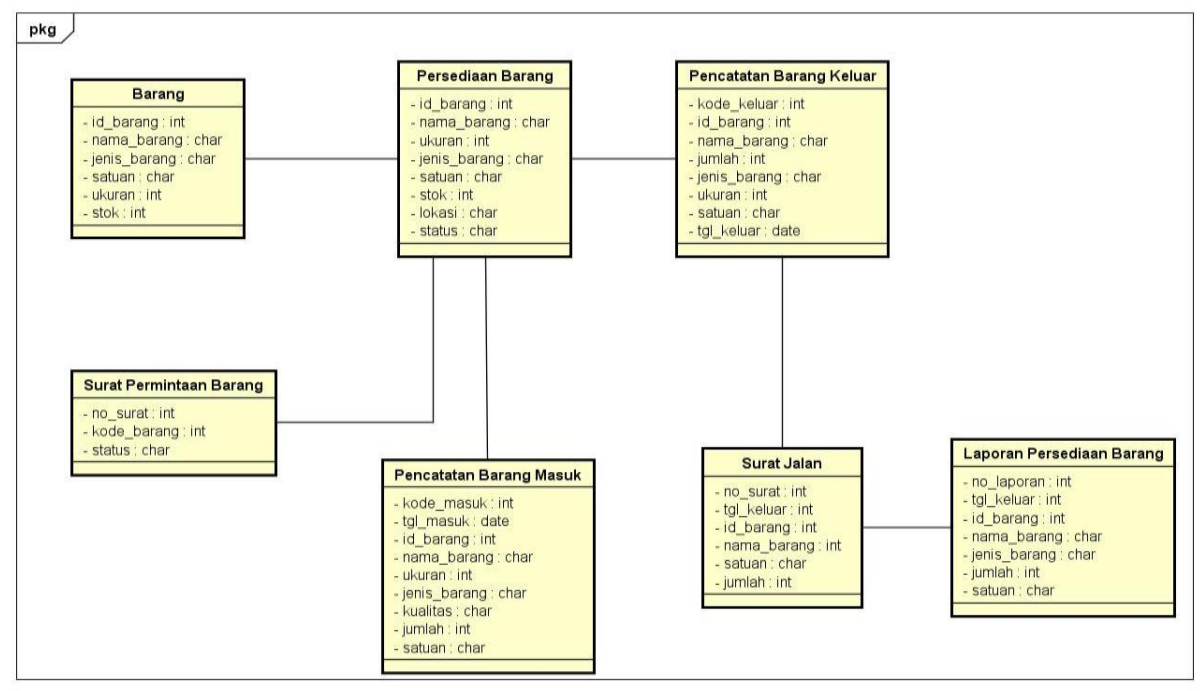

Gambar 12

\section{E. Deployment Diagram}

Class Diagram

Deployment diagram menggambarkan, memvisualisasikan, menspesifikasikan serta mendokumentasikan suatu proses yang terjadi dalam sebuah sistem.

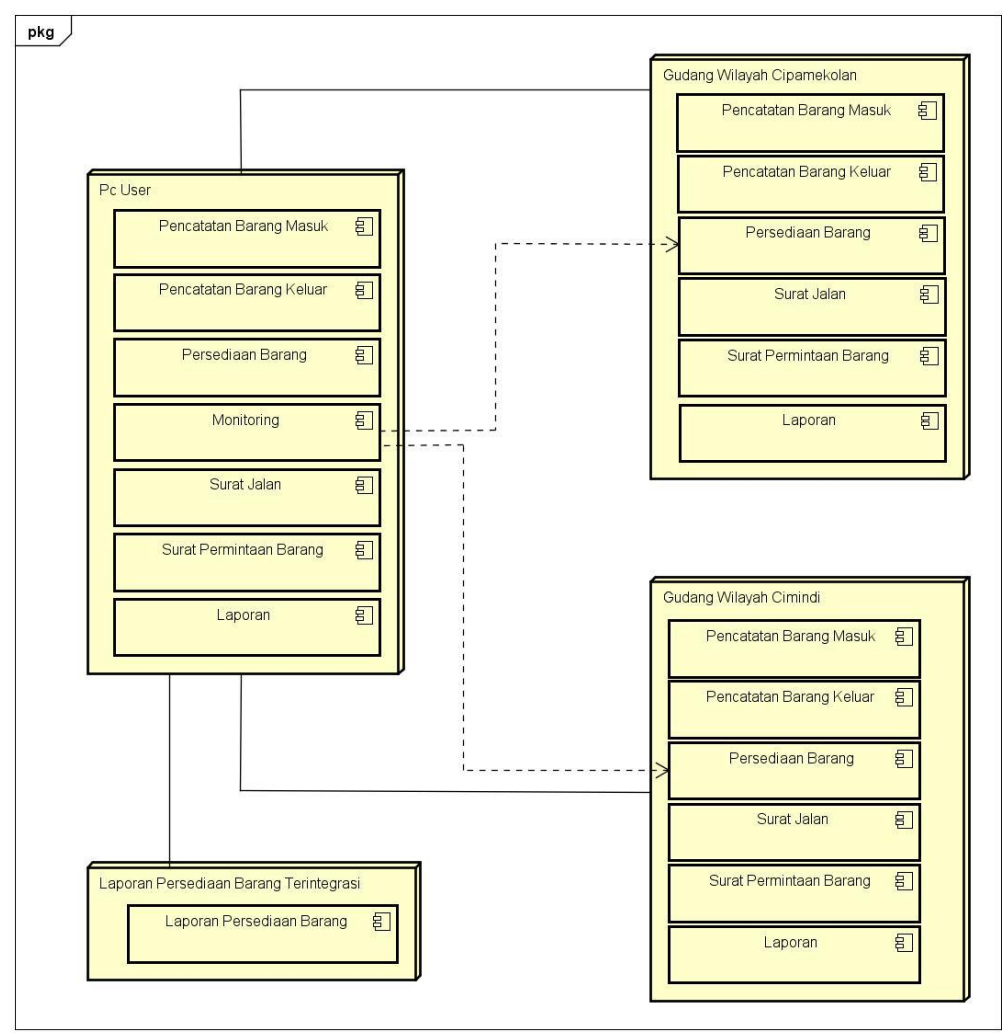

Gambar 13

Deployment Diagram pada Pembangunan Pelaporan

Data Persediaan Barang 


\section{F. Desain Pembangunan Pelaporan Data Peresediaan Barang}

a. User

Pada pembangunan pelaporan data persediaan barang, terdapat dua pengguna yang dapat mengakses sistem pembangunan pelaporan data persediaan barang yaitu gudang pusat dan gudang wilayah.

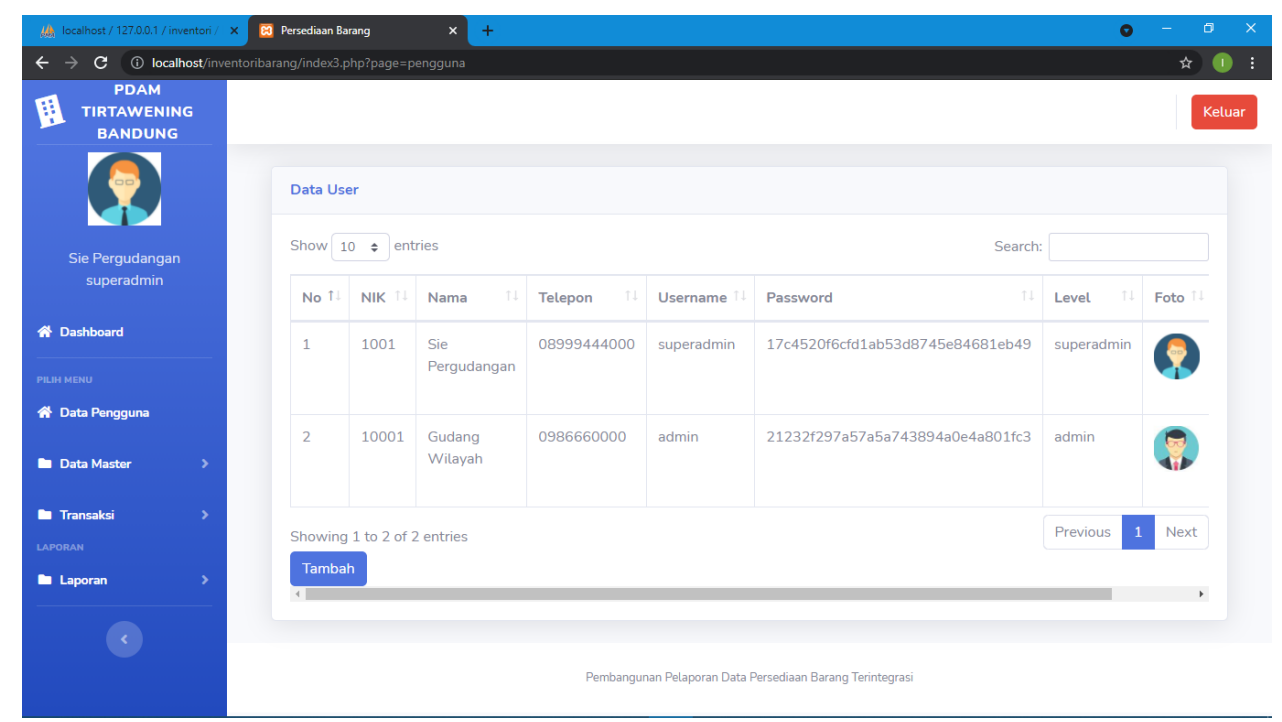

Gambar 14

User Pada Pembangunan Pelaporan Data Persediaan Barang

\section{b. Input Data Barang}

Input data barang dapat dilakukan oleh gudang pusat. Barang yang akan diperlukan oleh perusahaan akan di inputkan terlebih dahulu untuk mengetahui barang apa saja yang diperlukan pada saat melakukan pemesanan atau melakukan pencatatan barang masuk dan keluar.

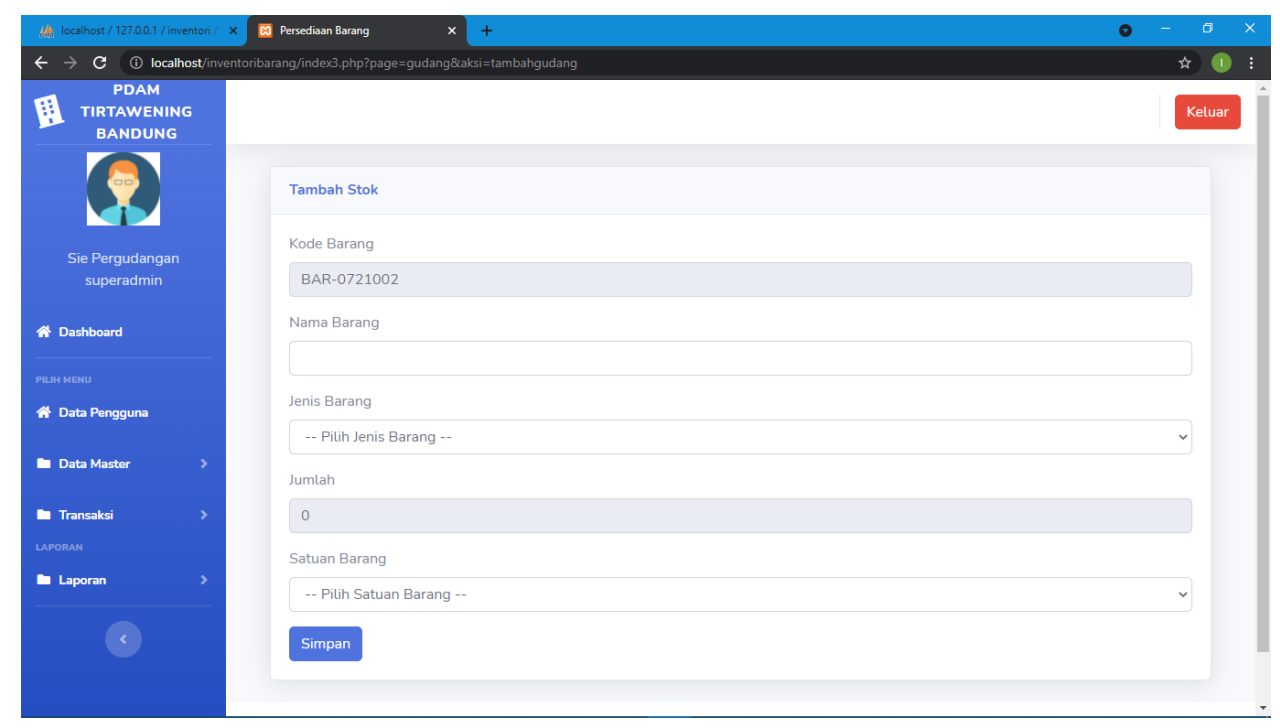

Gambar 15

Input Data Barang 


\section{c. Pencatatan Barang Masuk}

Pencatatan barang masuk dilakukan oleh gudang pusat dan gudang wilayah yang akan diperbaharui secara otomatis barang yang masuk berada gudang wilayah atau gudang pusat.

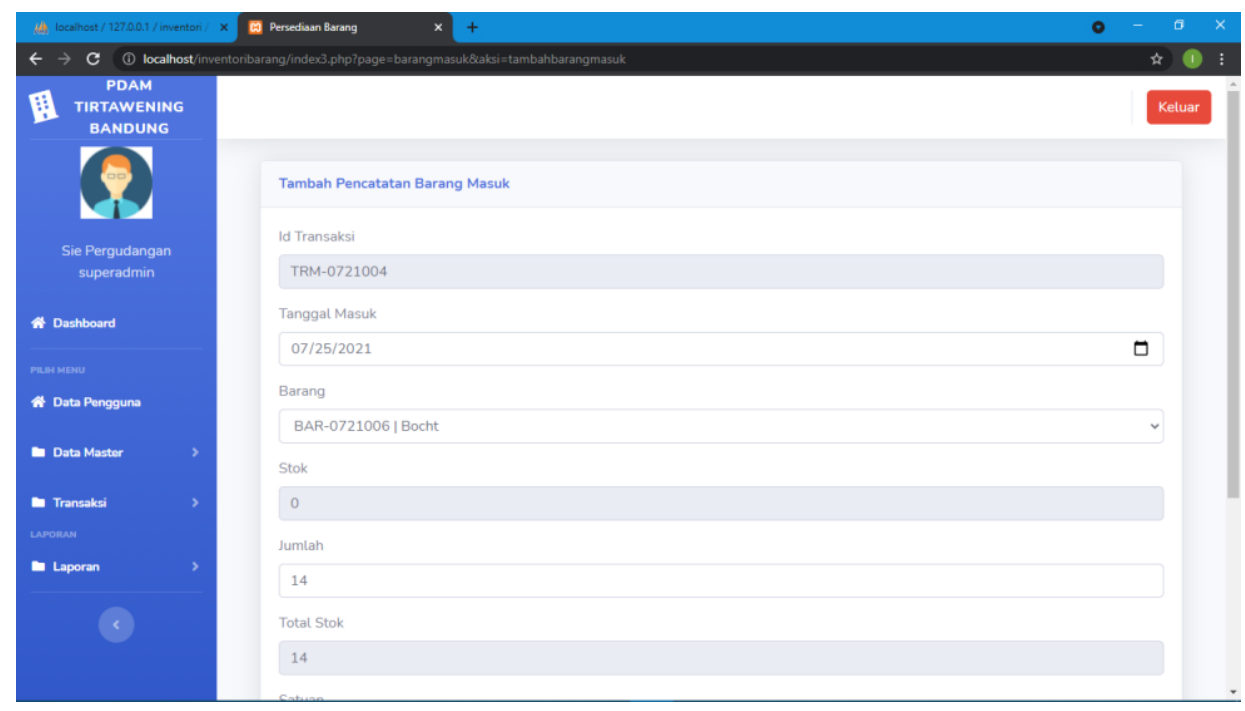

\section{Gambar 16}

Pencatatan Barang Masuk

\section{d. Pencatatan Barang Keluar}

Pencatatan barang keluar dapat dilakukan oleh gudang wilayah ata gudang pusat, dimana dapat dilakukan apabila terdapat permohonan permintaan barang dan barang tersebut berada di lokasi gudang pusat atau gudang wilayah. Maka gudang tersebut melakukan proses pencatatan barang keluar berdasarkan lokasi gudang.

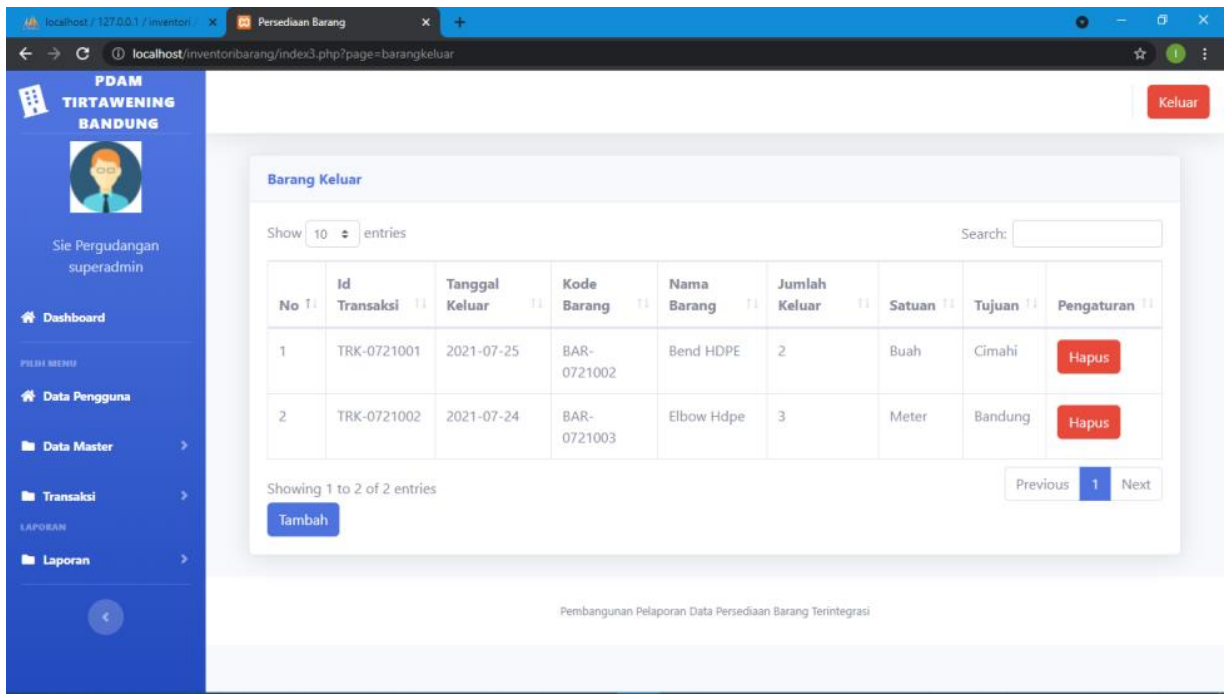

Gambar 17

Pencatatan Barang Keluar 


\section{e. Persediaan Barang}

Persediaan barang menyimpan barang dari gudang pusat dan gudang wilayah, yang telah terintegrasi atau terhubung serta dapat diperbaharui sehingga penyimpanan barang dapat di masukan dari gudang mana saja dan kapan saja.

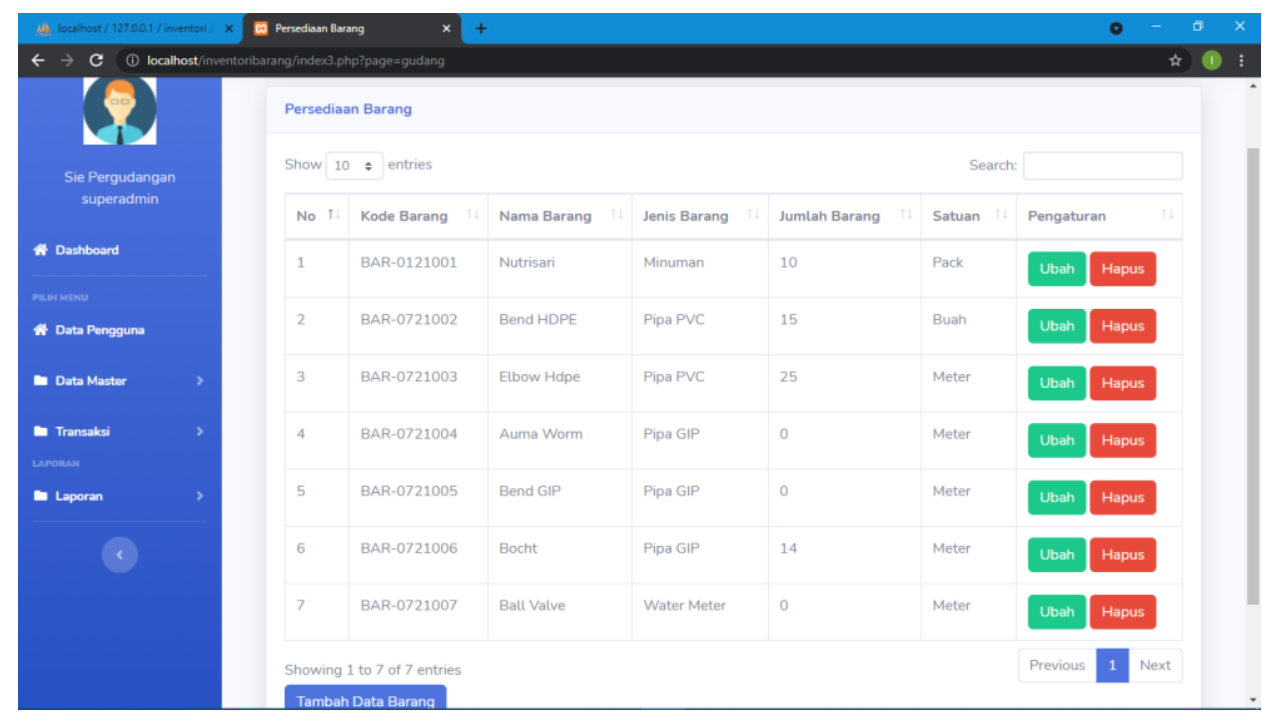

\section{Gambar 18}

Persediaan Barang

\section{f. Laporan Persediaan Barang}

Laporan persediaan barang akan memberikan informasi pelaporan persediaan barang secara keseluruhan.

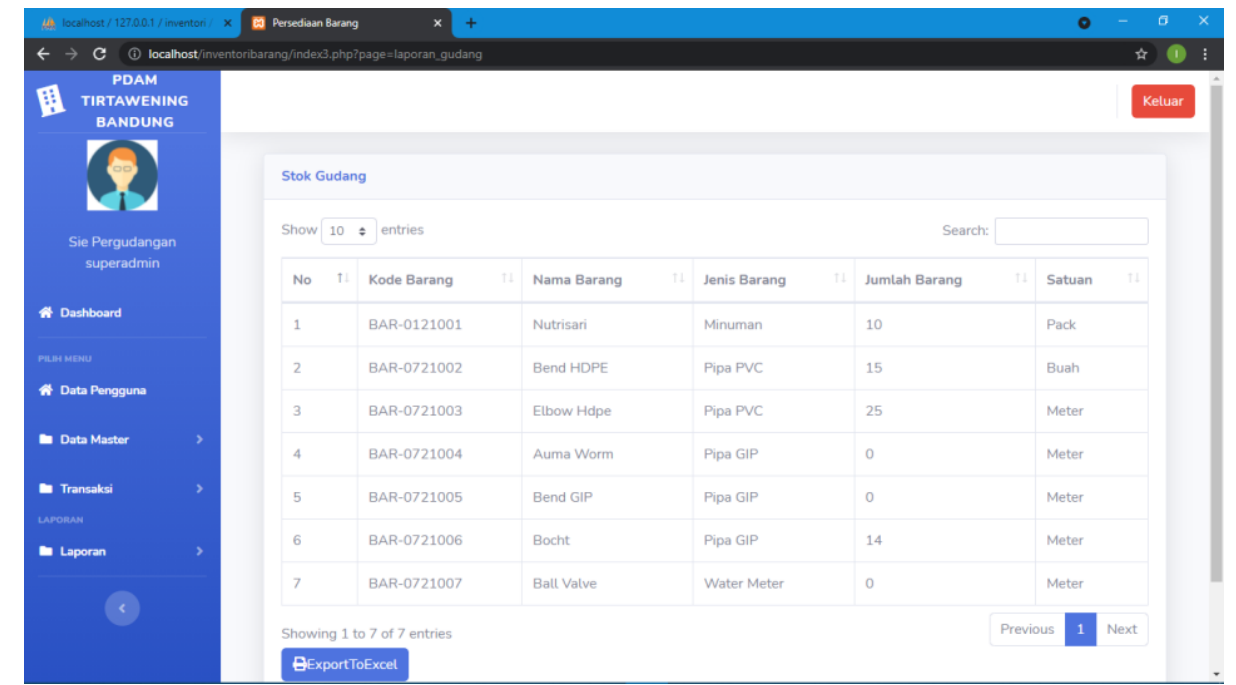

Gambar 19

Laporan Persediaan Barang 


\section{Kesimpulan}

Berdasarkan hasil perancangan yang telah dibuat oleh penulis dapat disimpulkan dari perancangan ini pembangunan pelaporan persediaan barang dapat memberikan solusi untuk menyelesaikan masalah perusahaan. Dengan adanya sistem pelaporan data persediaan barang terintegrasi ini dapat membudahkan pengguna dalam mendapatkan informasi persediaan barang secara keseluruhan serta dapat memonitoring persediaan barang yang tersimpan di gudang yang berbeda. Membantu mengambil keputusan dari informasi yang didapat dari tiap gudang cabang. Sehingga memudahkan dalam membuat pelaporan persediaan barang secara keseluruhan. 


\section{BIBLIOGRAFI}

Agusvianto, H. (2017). Sistem Informasi Inventori Gudang Untuk Mengontrol Persediaan Barang Pada Gudang Studi Kasus: PT. Alaisys Sidoarjo. JIEET (Journal of Information Engineering and Educational Technology), 1 (1), 40-46. Google Scholar

Dwi Yulianto Andie Arvian Rachmadi, H. (2017). Perancangan Sistem Informasi Akuntansi Persediaan Barang Dagang berbasis Dekstop terintegrasi dengan web pada CV. Prima Sari Engineering. Prosiding Saintiks Ftik Unikom, 2. Google Scholar

Hendini, A. (2016). Pemodelan UML sistem informasi monitoring penjualan dan stok barang (studi kasus: distro zhezha pontianak). Jurnal Khatulistiwa Informatika, 4 (2). Google Scholar

Kurniawan, D. E., Saputra, A., \& Prasetyawan, P. (2018). Perancangan Sistem Terintegrasi pada Aplikasi Siklus Akuntansi dengan Evaluasi Technology Acceptance Model (TAM). Jurnal RESTI (Rekayasa Sistem Dan Teknologi Informasi), 2m (1), 315-321. Google Scholar

Muslihudin, M. (2016). Analisis Dan Perancangan Sistem Informasi Menggunakan Model Terstruktur Dan UML. Penerbit Andi. Google Scholar

Pahlevi, R., Birowo, A., \& Rezeki, S. (2021). Perancangan Sistem Pengelolaan Persediaan Barang pada PT Prima Indostar Lubritama. Jurnal Riset Dan Aplikasi Mahasiswa Informatika (JRAMI), 2 (02). Google Scholar

Pratama, A. (2018). Integrasi Sistem Informasi Persediaan Barang Pada Toko Cat Pd Utama. Google Scholar

Pratama, S. (2017). Sistem Informasi Inventori Barang Berbasis Intranet Terintegrasi Barcode Scanner Di Pt. Astragraphia, Tbk Depo Samarinda. Sistem Informasi. Google Scholar

Sari, A. O., \& Nuari, E. (2017). Rancang Bangun Sistem Informasi Persediaan Barang Berbasis Web Dengan Metode Fast (Framework For The Applications). Jurnal PILAR Nusa Mandiri, 13 (2), 261-266. Google Scholar

Taloko, F. I. R., Witanti, W., \& Umbara, F. R. (2020). Pembangunan Sistem Informasi Terintegrasi Untuk Optimalisasi Proses Produksi di PT XYZ. Seminar Nasional Teknologi Komputer \& Sains (Sainteks), 1 (1), 147-151. Google Scholar

Tamodia, W. (2013). Evaluasi penerapan sistem pengendalian intern untuk persediaan barang dagangan pada PT. Laris Manis Utama Cabang Manado. Jurnal Emba: Jurnal Riset Ekonomi, Manajemen, Bisnis Dan Akuntansi, 1 (3). Google Scholar 
Warkim, W., \& Sensuse, D. I. (2017). Model Integrasi Sistem Dengan Pendekatan Metode Service Oriented Architecture Dan Model View Controller Pada Pusat Penelitian Perkembangan Iptek Lembaga Ilmu Pengetahuan Indonesia. JuTISI (Jurnal Teknik Informatika Dan Sistem Informasi), 3 (1). Google Scholar

Wijaya, A., Arifin, M., \& Subiyanto, T. (2013). Rancang Bangun Sistem Informasi Perencanaan Persediaan Barang. Universitas Dinamika. Google Scholar

Yuhendra, Y. (2014). Perancangan Sistem Inventory Spare Parts Mobil Pada Cv. Auto Parts Toyota Berbasis Aplikasi Java. Jurnal Teknoif, 1 (2). Google Scholar

Zaidir, A. A. (2017). Analisis Dan Perancangan Sistem Informasi Terintegrasi untuk Manajemen Produksi, Persediaan dan Distribusi Barang (Studi Kasus:Pabrik Kemasan Kertas CV. Yogyakartas). Respati, 12 (2). Google Scholar

Copyright holder:

Indah Putriani Fajar Sidik, Wina Witanti, Asep Id Hadiana (2021)

First publication right:

Jurnal Syntax Admiration

This article is licensed under: 